\title{
An Analysis of Road Network in Supporting Transport of Containers for Agropolitan Commodities in Enrekang Regency, South Sulawesi, Indonesia
}

\author{
Widiany $^{1}$, M. Yamin Jinca ${ }^{2}$, Ganding Sitepu ${ }^{3}$ \\ ${ }^{1}$ Master Degree of Transportation Planning, Hasanuddin University \\ ${ }^{2}$ Professor, for Infrastructure and Transportation Planning, Hasanuddin University, \\ ${ }^{3}$ Lecturer, Transportation Engineering, Hasanuddin University
}

\begin{abstract}
The development of Agropolitan commodities in Enrekang Regency is more increase, especially transportation demand for inter-regional trading commodities, moreover ushered inter-island trade. Transport commodity with conventional systems (truck), leading to container transport in anticipation of cargo to be delivered inter-island. This study analyzes the container transport demand for Agropolitan commodities that may be boxed and its relation to the performance of the road construction and geometric as well as access to terminal handling Agropolitan roads in supporting the container transport. The analysis shows that the potential demand for container transport commodity crops-fruits and vegetables high enough. Performance roads are possible for the development of vehicle access to the container terminal handling Agropolitan requiring width adjustment and geometric road, road structure adjustment and periodic road maintenance and new road construction alternatives.
\end{abstract}

Keywords: Demand of Trading, Container transport, Road Geometric

\section{Introduction}

Infrastructure building is the main condition of economic development, because a remote area can be interlinked to the domestic market at affordable transport costs. The better conditions of the road infrastructures are the lower cost of transportation and main contribution to economic growth [1]. The success of the agricultural sector in Enrekang Regency is able to lift the economy, society, due to the support the availability of adequate resources. The availability of fertile land allows the development of various commodities, food crops and horticulture as well as a variety of other agricultural commodities [2].

Agropolitan products are mostly inter-island to Kalimantan Island, NTT, NTB, Maluku, North Maluku and Papua through Pare-Pare and Makassar port. Agropolitan product distribution process in Enrekang Regency is the port to be carried out by the conventional transport container transport truck [3]. Transport of logistics, especially container requires adequate infrastructure to operate, on the other hand, the highway also needs to be improved construction and geometrical roads according to class and tonnage container transport [4]. Cargo transport containers are different from the transport of general cargo. In addition to its large, namely containers of 20 feet with a weight of 24 tons and a container 40 feet with a weight of 48 tons, ideally of axial load the road transport containers over 10 tons, minimum width of 11 meters, so as not to cause damage to roads that do not fit the design life and will not interfere with traffic traveling with their transport containers [5,6].

Recommendations from "highway and road transport consultancy projects" based on vehicle weight and dimension studies recommend the heaviest single vehicle axle load 4 wheels and the heaviest tandem is eight wheels is 10.0 tons and 16.0 tons, maximum weight 40 tones vehicles, the maximum width $2,25 \mathrm{~m}$, a maximum height of $4.0 \mathrm{~m}$, and the maximum length of $18.0 \mathrm{~m}$ including payload $[5,8]$. Transport containers have special properties and not all roads impassable, then in need of a policy/regulation track and road special transport container that can be bypassed, so as to prevent and suppress the occurrence of damage to road construction and traffic jams, especially during rush hour on the road highway [7].

Visually service transport network still less able to meet the needs of the distribution of logistics, especially container vehicles load with container transport for inter-regional trading commodities. It is evident from the many road sections of a width not qualified technical that road capacity is low, the damaged surface conditions, vehicle load exceeds the capacity and lead to reduced performance of the road network [5]. Based on the problems described above, it is necessary to anticipate handling in order to improve the performance of the road network of the destination terminal to the region Agropolitan distribution and optimization of the movement of containers in support of product distribution Agropolitan in Enrekang Regency. Location of the agropolitan is in Alla district, while the roads were to be analyzed were Kalosi-Cece Road, Balai Kota Road, Pasar Agro Road and Baroko road. 


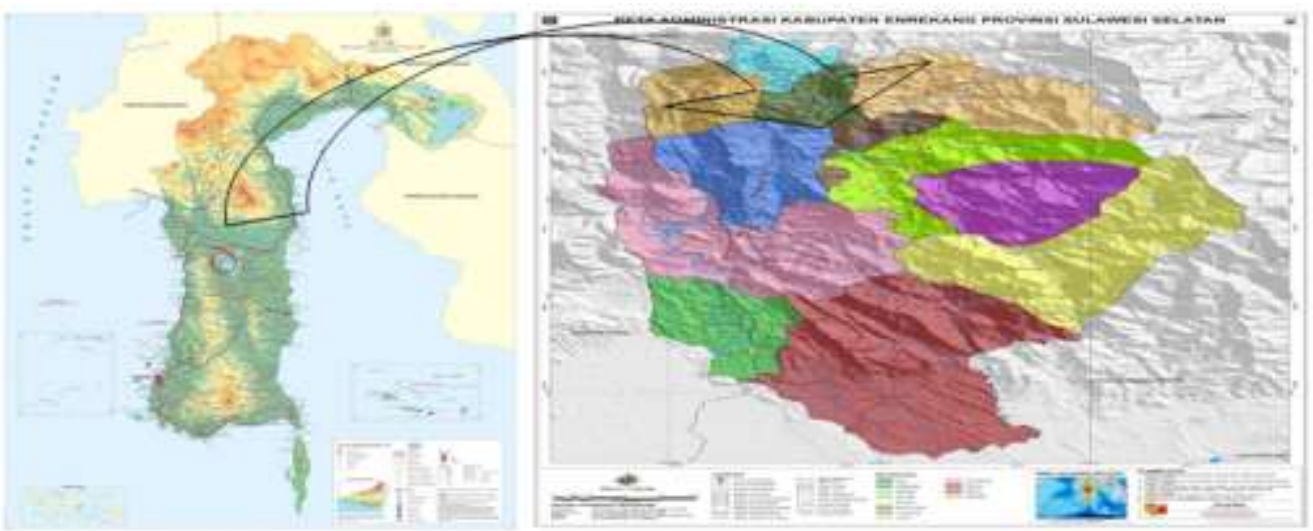

Figure 1. Location of agropolitant in Enrekang Regency, South Sulawesi, Indonesia

\section{Model of Commodity Distribution}

\section{Result And Discussion}

The type of cargo distributed mostly vegetable commodities. Internal distribution of Cargo Agropolitan products in South Sulawesi province has a frequency of transport services take place every day to travel long distances and varied. Modes of transport for internal distribution is dominated by 4 -wheel truck mode (load \pm 4 tons) with 2 types of vehicles (trucks and mini trucks), see in Figure 2.

Cargo distribution products of Agropolitan for inter-regional have a distribution relatively remote destination, then the frequency distribution can not be every day, lasting only 3 times a week. In contrast to the internal movements which only carry about 4 tons, inter-regional movement capable of hauling around 8 tons of all transports, it can be assumed as an efficient form of transport cost because the greater the load the divisor factor against the smaller the cost per load.
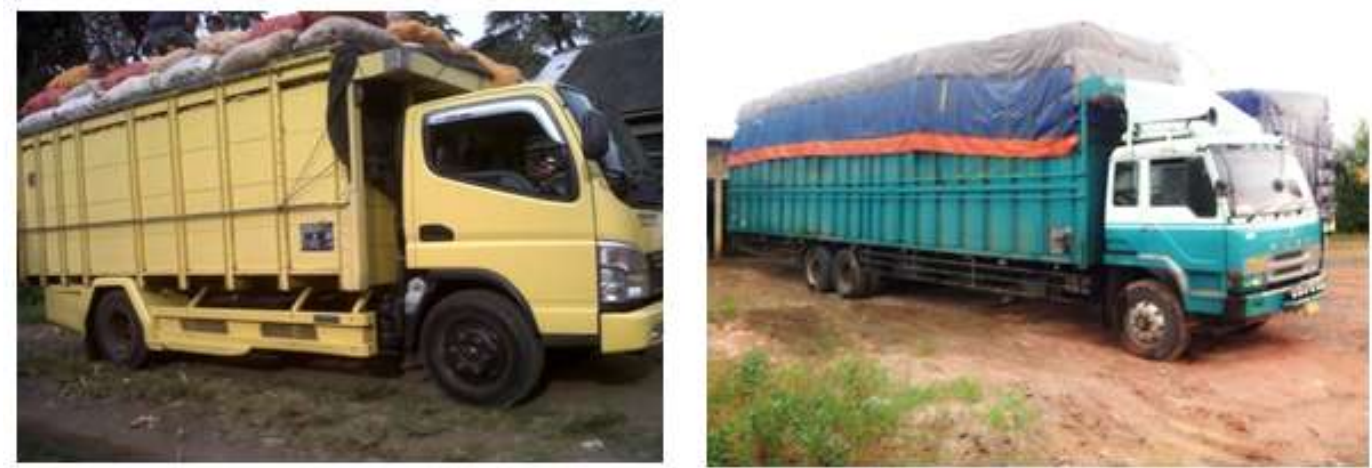

Figure 2. Type of truck commodity transport

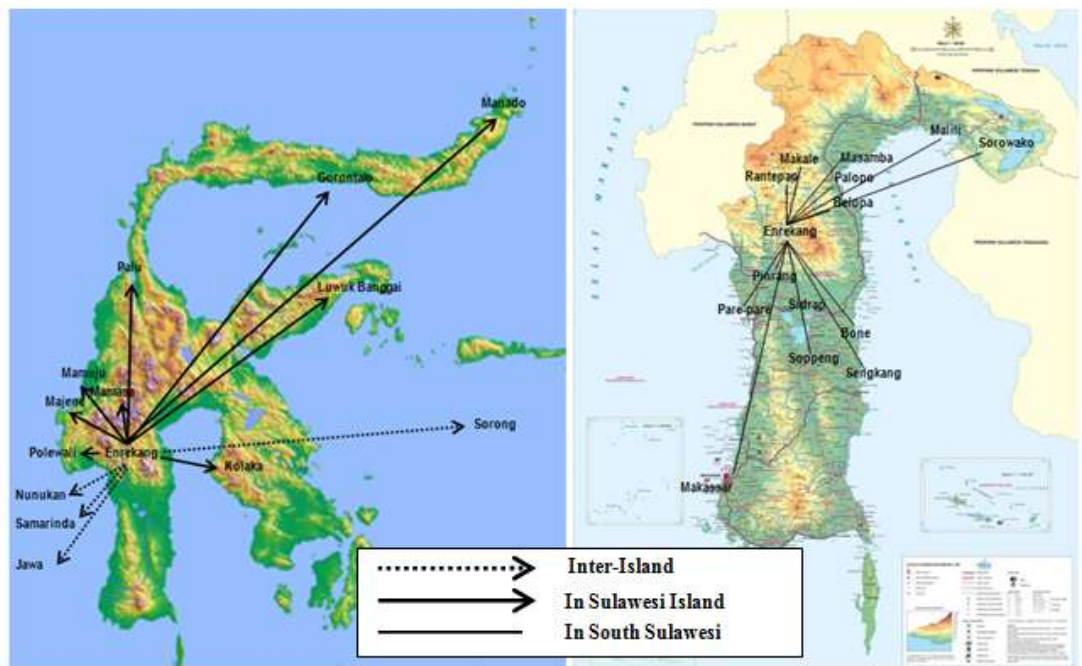

Figure 3. Distribution of Commodity Agropolitan 


\section{Transport Demand for Container}

Boxed agropolitan commodities are inter-regional trade (excluding the province of South Sulawesi and between the islands). Commodity demand model and plantation crops include other types of rice, maize, cassava and sweet potatoes. As for the head of plantation crops include plants, coffee, cloves, nutmeg, pepper, cocoa, hazelnut, cashew and vanilla. Modeling results for each commodity sector as follows:

$Y_{(\text {Crops })}=-156912+3,4209 X_{1}+5,2957 X_{2}+1,0192 X_{3}+0,3910 X_{4}+2,1291 X_{5}$

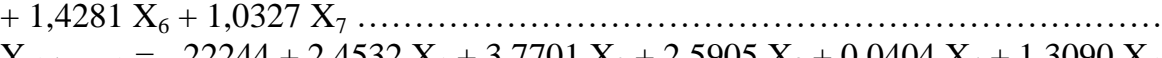

$\mathrm{Y}_{\text {(Plantage) }}=-22244+2,4532 \mathrm{X}_{1}+3,7701 \mathrm{X}_{2}+2,5905 \mathrm{X}_{3}+0,0404 \mathrm{X}_{4}+1,3090 \mathrm{X}_{5}$

$+0,2474 X_{6}+1,2444 X_{7}$

The meaning of symbols, i.e; population $\left(\mathrm{X}_{1}\right)$, the GDP $\left(\mathrm{X}_{2}\right)$, productivity of Agropolitan $\left(\mathrm{X}_{3}\right)$, the number of farmers $\left(\mathrm{X}_{4}\right)$, the income of farmers $\left(\mathrm{X}_{5}\right)$, the transport distance $\left(\mathrm{X}_{6}\right)$ and transportation cost $\left(\mathrm{X}_{7}\right)$.

The cargo commodities for distribution of inter-regional trade can be packaged as in the following table. Needs dry cargo containers ( 20 feet) per day in 2018 an estimated 6 TEUs, and for the next ten years developed into 10 TEUs.

Table 1. Container demand for Agropolitan Commodities

\begin{tabular}{|l|l|l|l|l|}
\hline \multirow{2}{*}{ Prediction of Commodity Cargo (ton) } & \multicolumn{4}{l}{ Prediction } \\
\cline { 2 - 6 } & 2018 & 2023 & 2028 & 2033 \\
\hline Crops & 84.490 & 100.687 & 129.791 & 152.442 \\
\hline Plantation & 35.016 & 48.085 & 61.153 & 74.222 \\
\hline Prediction total Commodities & 119.506 & 148.771 & 190.945 & 226.664 \\
\hline Internal Distribution & 47.803 & 59.509 & 76.378 & 90.666 \\
\hline *Inter-regional Trade & 71.704 & 89.263 & 114.567 & 135.998 \\
\hline Assumptions Using Containers 20 feet & \multicolumn{5}{|l}{} \\
\hline Dry needs Containers (TEUs) & 2.175 & 2.708 & 3.476 & 4.126 \\
\hline Total Container/year & 42 & 52 & 67 & 79 \\
\hline Total Container/week & & & \\
\hline
\end{tabular}

Notes: Dry container is only used for inter-regional trade for prediction of transport demand $60 \%$ of the total cargo is as an Agropolitann Commodities.

Commodity Transport demand and horticultural crops (vegetables and fruits) to be transported by reefer containers is as follows;

$Y_{(\text {Vegetables) }}=-94995+2,3780 X_{1}+4,0234 X_{2}+5,2907 X_{3}+0,0211 X_{4}+1,4310 X_{5}$

$+0,7905 \mathrm{X}_{6}+0,0413 \mathrm{X}_{7}$

$Y_{\text {(Fruits) }}=-232870+5,2898 X_{1}+3,2756 X_{2}+2,8482 X_{3}+0,0121 X_{4}+2,2341 X_{5}$

$+5,1244 X_{6}+3,6984 X_{7}$

The meaning of the symbol i.e. Population $\left(\mathrm{X}_{1}\right)$, the GDP $\left(\mathrm{X}_{2}\right)$, productivity Agropolitan product $\left(\mathrm{X}_{3}\right)$, the number of farmers $\left(X_{4}\right)$, the income of farmers $\left(X_{5}\right)$, the transport distance $\left(X_{6}\right)$ and transportation cost $\left(X_{7}\right)$.

The need to anticipate the reefer container cargo and horticultural crops (vegetables and fruits) in Enrekang Regency can be seen in Table 4.

Table 2. Refrigerator Container for Agropolitan Commodities

\begin{tabular}{|c|c|c|c|c|}
\hline \multirow[t]{2}{*}{ Demand of Fresh Cargo commodities (ton) } & \multicolumn{4}{|c|}{ Prediction } \\
\hline & 2018 & 2023 & 2028 & 2033 \\
\hline Vegetables & 220.035 & 299.585 & 379.137 & 458.687 \\
\hline Fruits & 80.035 & 108.919 & 137.804 & 141.688 \\
\hline Total Predictions Commodities & 300.069 & 408.504 & 516.941 & 600.375 \\
\hline Internal Distributed & 120.028 & 163.402 & 206.776 & 240.150 \\
\hline Inter-regional Trade & 180.042 & 245.102 & 310.164 & 360.225 \\
\hline \multicolumn{5}{|l|}{ Assumptions Using Containers $20 \mathrm{ft}$} \\
\hline \multicolumn{5}{|l|}{ Needs Refrigerator Container (TEUs) } \\
\hline Container/year & 6.339 & 8.630 & 10.921 & 12.684 \\
\hline Total Container/week & 122 & 166 & 210 & 244 \\
\hline
\end{tabular}




\section{Performance of Roads}

Segments of the access road to the Agropolitan terminals at Alla District consist of four roads as inter-nodes with different characteristics as in Table 3.

Table 3. Condition and type of roads in geometric

\begin{tabular}{|l|l|l|l|l|l|}
\hline \multirow{2}{*}{ No. } & \multirow{2}{*}{ Roads } & Geometric conditions & Surface type & \multirow{2}{*}{ Condition } \\
\cline { 3 - 5 } & & Type Rows & Length of Way & & \\
\hline 1 & Kalosi-Cece Roads & $2 / 2$ UD & $3 \mathrm{~km}$ & Asphalt & good \\
\hline 2 & Balai Kota Road & $2 / 2$ UD & $1,5 \mathrm{~km}$ & Asphalt & good \\
\hline 3 & Pasar Agro Road & $2 / 2$ UD & $1 \mathrm{~km}$ & Asphalt & good \\
\hline 4 & Baroko Road & $2 / 2$ UD & $4 \mathrm{~km}$ & Asphalt & good \\
\hline
\end{tabular}

Source: Field Surveys, 2017

The results show that the axis road Kalosi-Cece, Balai Kota Street, Pasar Agro Road and Baroko Road has a capacity of $1400 \mathrm{pcu} /$ hour. Degree of saturation [8,9] every street is under 0.75 , the capacity is calculated based on basic capacities $\mathrm{CO}=2.900 \mathrm{pcu} /$ hour, and correction factor totally about $\mathrm{Cf}=0,485$, nearing the threshold road performance from peak hours, it can be concluded that all four of these roads still have a good performance.

Table 4. Degree of Saturation and Level of Service

\begin{tabular}{|l|l|l|l|l|l|}
\hline No. & Roads & $\begin{array}{l}\text { Traffic Flow (Q) } \\
(\mathrm{pcu} / \text { hour })\end{array}$ & $\begin{array}{l}\text { Capacity } \\
(\mathrm{pcu} / \text { hour })\end{array}$ & DS & $\begin{array}{l}\text { Level of Services } \\
(\text { LoS })\end{array}$ \\
\hline 1 & Kalosi-Cece Road & 296 & 1405 & $\mathbf{0 , 2 1}$ & $\mathbf{A}$ \\
\hline 2 & Balai Kota Road & 198 & 1405 & $\mathbf{0 , 1 4}$ & $\mathbf{A}$ \\
\hline 3 & Pasar Agro Road & 203 & 1405 & $\mathbf{0 , 1 4}$ & $\mathbf{A}$ \\
\hline 4 & Baroko Road & 270 & 1405 & $\mathbf{0 , 1 9}$ & $\mathbf{A}$ \\
\hline
\end{tabular}

Source: Result Analysis, 2017

Road network performance is expected to be passed by container load has a level of service is a category "A", this road was the potential for driving the container. However, the geometric conditions need to be improved/repaired because of elevation of the access road to the agropolitan terminals are generally larger $15^{0}$, very risky to maneuver the container vehicles. With a width of only 4 meters way, is not currently possible to make the distribution of logistics containers directly from the terminal of Agropolitan. So that the required widening of the road a minimum radius turn off 45 feet and structural improvements single axle load weighing 15 tons $[8,10]$.

\section{Priority of Roads Improvement}

Potentially passable roads for container vehicles are according to the analysis of Hierarchy Process (AHP) show that the weighting of alternative roads to all the criteria, the ranking priority improvement is; i) Baroko road (weight 0.336), ii) Kalosi-Cece road (weight 0.241), iii) Pasar Agro road (weight 0.218), and iv) Balai Kota streets (weight 0.204)

An inconsistency volume is 0.03 so that the level of confidence in the selection of respondents said rated 'good'. By him therefore, based on the rank order, we can conclude that the road chosen is Baroko road.

Priority handling to improve the roads in anticipation of a container vehicles transport is the first priority for adaptation width and geometric roads, maintenance of damaged roads and construction of new roads.

Handling these roads should be done gradually in accordance with the development of container transport demand. For now, the urge to do is adjust the width and the geometric of Baroko roads in order to accommodate the entry and exit activity Agropolitan container terminal that does not interfere with the vehicle maneuver containers. Adjustment of the road structure to hold the load of container vehicles $>15-20$ tons, and carry out road maintenance on a regular basis when adjusting the width and the geometric and structural adjustment of road has been carried out, with the assumption that the loading of logistics at the terminal Agropolitan death containerize system has taken place. The final choice to build a new road can be done if in the next few years and the increased activity containerize considered Baroko roads were not able to bear the burden of an increasingly dense traffic. More priority handling Baroko road transport operations in anticipation of the container can be seen in Figure 5.

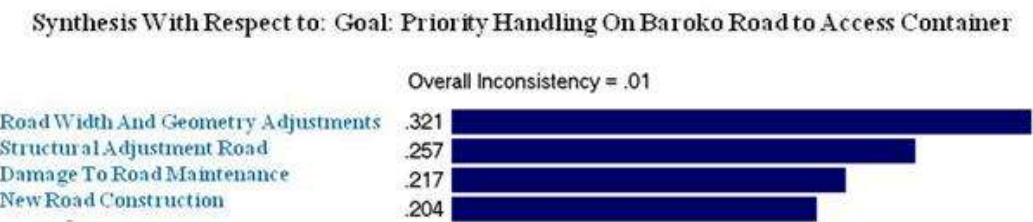

Figure 4. Priority rating of improvement structure and Geometric of Baroko Roads 


\section{Conclusion}

Container transport demand for agricultural commodities and plantations, vegetables and fruits is very potential for refrigerator containers. The performance of the Level of Service (LoS) the road for container transport to distribute of Agropolitan commodities have categories "A" with a Volume Capacity Ratio (VCR) about 0.14 to 0.21 . Traffic was still the potential to pass the container transport. The geometric needs to be reevaluated because of the greater general than $15^{\circ}$, it is very risky to maneuver the container vehicles.

Roads are often impassable container vehicles transport for access to the agropolitan terminals are a segment Baroko road. To anticipate containerize transport system, it is necessary to adjust the width and geometric road, the road structure to withstand a load of container vehicles > 15-20 tons, periodic road maintenance and new road construction, for the next few years according to activity of loading and unloading of containers.

\section{Acknowledgements}

The author would like to thank the highest possible to Pusbiktek-BPSDM Ministry of Public Works and Public Housing, who has given scholarships and the opportunity to attend the Master program of Transportation Engineering, Hasanuddin University in 2015 to 2017 and the Government of Enrekang Regency as an Allower task of learning which has given an opportunity to continue their education.

\section{References}

[1]. Tamin, OZ, 2002. Planning and Transport Modeling, Volume 2. Publisher ITB. Bandung

[2]. Adisasmita, Rahardjo, (2005). Analysis of the Territory and Transport Infrastructure. Infrastructure Cooperation and Postgraduate Program of Hasanuddin University. Makassar

[3]. Adisasmita, Rahardjo. (2005). Transport Economics. Postgraduate Program of Hasanuddin University. Makassar.

[4]. Law no. 22 of 004, Traffic and Transportation of Logistics

[5]. Jinca, M.Y., (2008), Anticipation the Growth of Container Technology to the Infrastructure and Transport Facilities Multimodal, Publication FSTPT, UGM.

[6]. Napitulu, E., (2010), Effect of Systemic Analysis of Container Transport against Congestion Cost, Conception Dissertation Proposal, DTS Diponegoro University in Semarang

[7]. Kambu. Zepnat, (2014), Analysis of Primary Arterial Road Transport Network Keertanipura In Anticipating the Cargo Traffic Containers, Thesis, Hasanuddin University, Unpublished.

[8]. Morlock, E.K., 1991, Introduction to Engineering and Transportation Planning, Erlangga, Jakarta

[9]. Khisty, C.J. (2005), Fundamentals of Transportation Engineering, third edition, vol. 2, Erlangga, Jakarta

[10]. Ministry of Public Works General Directorate of Highways, 1997, Indonesian Highway Capacity Manual (IHCM), Jakarta. 